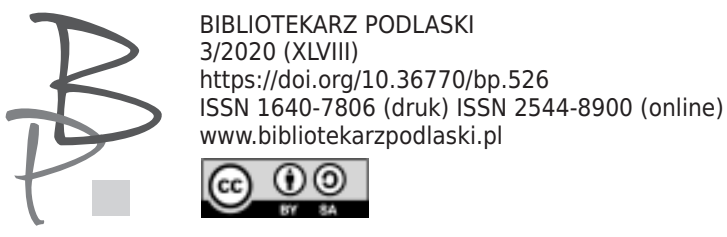

\title{
Valentina Musiy*
}

Odeski Narodowy Uniwersytet im. Jlji Miecznikowa, Ukraina https://orcid.org/0000-0002-9641-7753

\section{Топос „Одесса” в романе Сергея Ануфриева и Павла Пепперштейна „Мифогенная любовь каст”}

Topos "Odessa" in novel by Sergey Anufriev and Pavel Pepperstain Mythogenic love of castes

Abstract: The article deals with reflections in literature of the process of mythologizing the image of Odessa. The author understands the myth as a symbolic designation of objects, historical events, objects of the external world, belonging to the space of psychic reality. The purpose of mythologizing as a process is the expression of a generalized idea of something or someone, as well as imbuing events, persons, and objects with a universal sense. The subject of the article is the novel of the modern writers S. Anufriev and Pepperstein "Mythogenic love of castes". Both writers are organizers of the Medical Hermeneutics group and refer to themselves as younger conceptualists. Such postmodern writers pay special attention to various senses that are tra-

\footnotetext{
* Valentina Musiy - prof. dr Odeskiego Narodowego Uniwersytetu im. I. Miecznikowa w Odessie (Ukraina). Autorka monografii: „,... patrzac z namystem na szerokie niebo”: czlowiek i natura w pracach I.S. Turgieniewa 1840-1850 \{,,...глядя задумчиво в небо широкое”: человек и природа в произведениях И.С. Тургенева 1840-1850-х г2\} (Odessa 2016).
} 
ditionally attached to phrases, attitudes, and concepts. In the novel by Anufriev and Pepperstein, the reader is invited into the space of a fabulous, psychic (virtual) and historical reality. The novel refers to the events of the Second World War, it's hero takes part in key battles with the Nazis. However, fabulous heroes help him to defeat. The reader observes these events as they would be perceived by a participant during the war in the early 1940s and at the same time, by a modern person living at the end of the twentieth century. An image of Odessa is created in the twenty-first chapter of the novel. It names the real historical persons (Badayev, and Yasha Gordienko). These heroes take part in fictional events along with fictional characters. The article considers such historical sites of Odessa: Deribasovskaya street, Opera House, Archaeological Museum, the sea, and sea port. The article contains words that relate to the "Odessa" language and their meanings. Special attention is paid to Odessa songs (folklore and author's). At the same time, attention is drawn to the lack of historical accuracy in a number of images and details. Odessa in the novel by Anufriev and Pepperstein is both a real city and a city that has turned into myth.

Keywords: myth, signature, psychic reality, "Odessa" language, historical accuracy.

В науке уже утвердилось понимание мифа как словесного выражения ментальной реальности, которая как для целого коллектива, так и для отдельного человека, является не менее достоверной, чем физическая реальность. Отсюда - непрекращающийся процесс мифологизации событий, личностей, др. объектов внешнего мира. Первый том романа „Мифогенная любовь каст”, о котором пойдет речь, был написан Сергеем Ануфриевым и Павлом Пепперштейном и опубликован в 1999 году. Второй том, написанный только П. Пепперштейном, вышел в 2002 году. Оба автора, вместе с Юрием Лейдерманом организовали группу „Медицинская герменевтика”. Все они относят себя к младшим концептуалистам. 
Первый том романа состоит из двух частей („Востряков и Тарковский” и „Ортодоксальная избушка”). Действие в каждой из них происходит в лесу, который, в соответствии с мифопоэтической моделью мира, является местом инициации. Однако в первой части лес - разомкнутое пространство. Здесь находится лаборатория, в которой трудятся сотрудники, проживающие в деревне. В Лесную лабораторию приходят письма из большого мира, да и сами ее сотрудники бывают в Москве, Новосибирске, на симпозиумах за границей. В центре внимания - инженер Востряков, который во время войны стал свидетелем, как ему показалось, гибели парторга Дунаева, он до сих пор винит себя в случившемся, и внезапно, через много лет, начинает получать от того письма, из которых следует, что Дунаев жив и стал волшебником.

Во второй части (больше, чем в десять раз превышающей первую по объему) романа лес уже иной. Это не просто замкнутое, отделенное от большого мира пространство, но и противопоставленное ему как потустороннее. Центральное лицо второй части - парторг Дунаев, продолжающий после контузии сражаться с фашистами, но теперь уже с помощью сказочных сил. Сюжет строится циклически: действие включает в себя многочисленные остановки Дунаева, повторяющие основные вехи войны 1941-1945 гг. (Брест, Смоленск, Киев, Одесса, Севастополь, Москва, Ленинград, Карелия). Таким образом, во второй части романа можно выделить несколько различных хронотопов: исторический - „война в большом ракурсе”; психологический - „война, которую ведет один человек, бывший парторг Дунаев”; сказочный - „лес и ортодоксальная избушка". Ключевую роль в романе играет психологический хронотоп, моделируемый сознанием самого героя и подчиняющийся только его законам. Поэтому Д. А. Маркова определила „Мифогенную любовь каст” как „роман о Второй мировой войне, где ее осмысление практически полностью выведено за пределы и реальной истории, и этической сферы буквально вытеснено в сферу эстетическую"”.

По словам исследовательницы, подобный подход к войне дал авторам возможность воплотить „двойственное отношение” к ней человека

1 Д. А. Маркова, История как сказка: освоение военного мифа в романе „Мифогенная любовь каст”, ,Знание. Понимание. Умение” 2005, № 2, s. 165. 
1990-х годов: „и как историческое событие, относящееся к каждому из нас, и как миф, значимый, но отчужденный от него лично"2. Определяя причины подобного, Д. А. Маркова пишет:

...перед нами попытка приблизить к себе историю, определенное историческое событие, вернуть его из состояния застывшего монумента, памятника в сферу актуальных переживаний автора и читателя. Для этого авторы стремятся высвободить образы, принадлежащие к сфере бессознательного...3.

Исследовательница ведет речь о „Мифогенной любви каст” как о произведении, относящемся к концептуализму, ссылаясь, в частности, на то определение его жанра, которое предложил П. Пепперштейн - „психоделический роман".

То, что мир представлен в романе в мифопоэтическом облике, задано уже на уровне такого его перитекстуального элемента, как заглавие: „Мифогенная любовь каст”. Мифологизированы в романе С. Ануфриева и П. Пепперштейна не только персонажи и события, но и топосы. Одним из них является Одесса, которой посвящена двадцать первая глава. Но перед тем, как начать разговор о ней, обозначим наше понимание содержания категории „топос”.

В настоящее время ее используют в нескольких значениях. Вопервых, ею обозначается „значимое для художественного текста 〈...〉 “место разворачивания смыслов", которое может коррелировать с какимлибо фрагментом (или фрагментами) реального пространства, как правило, открытым"4, „клишированный образ, мотив, мысль, в том числе - „устойчивые пейзажные мотивы” (А. Е. Махов) ${ }^{5}$, „пространственные ориентиры” (И. Б. Роднянская), объекты, которые создают „простран-

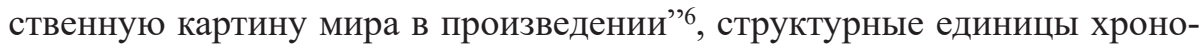

2 Д. А. Маркова, dz. cyt., s. 165.

3 Tamże, s. 166.

4 В. Ю. Прокофьева, Категория пространство в художественном преломлении: локуcы и топосы, ,Вестник Оренбургского гос. ун-та.” 2005, № 11, s. 89.

5 Литературная энциклопедия терминов и понятий, pod red. А. Н. Николюкина, Москва 2003, s. 1076.

6 А. А. Булгакова, Топика в литературном процессе, Гродно 2008, s. 40. 
топа, являющиеся образными универсалиями и потому служащие средством межкультурной коммуникации 7 . Во-вторых, топос - это „“общее место”, набор устойчивых речевых формул, а также общих проблем и сюжетов, характерных для национальной литературы". Ю. М. Лотман толковал „топос” как „весь пространственный континуум текста”9. В нашей статье этим понятием охвачены те составляющие образа художественного пространства, с которыми связаны события, играющие в произведении знаковую роль. Их включение в текст романа обусловлено аксиологическими приоритетами авторов. Кроме того, они наделены в произведении универсальным, вневременным смыслом.

Из двадцать первой главы романа „Мифогенная любовь каст” читатель узнает, что Дунаев прибывает в Одессу с тем, чтобы организовать в ней подполье. Партизанское движение - одно из наиболее значимых для Одессы военных лет явлений. Историк Александр Бабич выделил в его истории два периода:

Первый приходится на 1941-1942 гг., когда в катакомбы уходили по приказу. Действия этих отрядов координировали представители разведки армии и НКВД, а общее руководство осуществляли партийные органы.

Второй период датируется последними месяцами оккупации, когда отряды организовывали добровольцы и люди, стремившиеся заработать авторитет перед приходом Красной Армии 10

Одесская глава „Мифогенной любви” каст представляет город начала войны, „в последние дни свободы”"1. Это был период, когда организация сопротивления была наиболее сложной в силу целого ряда обстоятельств: большую часть оставшегося в тылу населения составляли

7 Е. В. Крикливец, Художественный мир В. Астафьева и В. Козько: пространственно-временная организация: Монография, Витебск 2014, s. 20.

8 В. Ю. Прокофьева, dz. суt., s. 89.

9 Ю. М. Лотман, В школе поэтического слова: Пушкин. Лермонтов. Гоголь, Москва 1988, s. 280.

10 А. Бабич, Как организовывалось одесское подполье, „Дерибасовская - Ришельевская. Альманах" 2013, № 3(54), s. 58.

11 С. Ануфриев, П. Пепперштейн, Мифогенная любовь каст, Москва 1999, s. 171. 
Valentina Musiy, Topos "Odessa" in novel by Sergey Anufriev and Pavel Pepperstain...

женщины, дети, старики и мужчины непризывного возраста; не все они были лояльны к идеям большевизма. В этом плане показательно, как продавец пива в романе С. Ануфриева и П. Пепперштейна оценивает происходящее:

- Вы ж понимаете, время такое, шо хоть стой хоть падай! До чего мы дожили - Страшный суд! Какие могут быть купюры? Товарищ Сталин до своей жинки говорит: „Собирай гардероб!”. И со сберкнижки последние гроши снимает! Так шо пейте и веселитесь, пока Соломон во гробе не перевернулся! Ваше здоровье! 12

Но самую большую опасность представляло укрепление в среде сталинского руководства мнения, что приближающаяся война завершится „малой кровью” и будет происходить на чужой территории. В результате, замечает А. Бабич, была ослаблена качественно и грамотно проводившаяся в конце 1920-начале 1930-х годов подготовка к партизанской войне, не были заранее подготовлены базы с оружием и продовольствием, не подобраны специалисты, отсутствовала конспиративная сеть - все это „пришлось делать спешно в конце лета и начале осени 1941 года"13.

Эти выводы историка приводим здесь потому, что они могут дать одну из мотивировок того, что в „Мифогенной любви каст” будущие подпольщики представлены вчерашними уголовниками. Это относится не только к вымышленным персонажам, но и к реальным историческим личностям, Бадаю и Яшке. Читатель-одессит сразу понимает, что идет речь о В. А. Молодцове (Бадаеве), командире одного из партизанских отрядов, 17 человек из которого осталось в живых, а 35 погибло. А также о Якове Гордиенко, именем которого был назван Дворец пионеров в Одессе. Представляя „чернявого и оборванного” мальчугана, Бадай говорит Дунаеву: „Яшка, наш связной, по воровскому делу мастак. Паханом будет!”14. Хотя можно предположить, что более важную роль в данном случае сыграла

12 Tamże, s. 171-172.

13 А. Бабич, dz. cyt., s. 58-60.

14 С. Ануфриев, П. Пепперштейн, dz. cyt., s. 169. 
показательная для Одесского текста романтизация уголовников. Вспомним хотя бы Беню Крика из „Одесских рассказов” И. Бабеля. Парторг Дунаев поясняет будущим подпольщикам их задачу:

- Вот что, ребята, я вам скажу! - говорил Дунаев собравшимся. - Немцы будут в городе со дня на день. Советские войска уйдут в Крым. Но ведь не все уйдут. Люди-то останутся! И вот теперь вам выпадает на долю великий подвиг, почище ваших налетов. Вы остаетесь, пути с армией вам нет. Город отдадут румынам, а они - распиздяи. Вот и раздолье для вашего брата! Постоянно держите связь с Большой землей и сообщайте о ситуации. Все разведывать, и прежде всего - дислокация войск, арсеналы, комендатура, полиция, списки предателей, ушедших на службу к захватчикам. Где только можно, необходимо вредить, не брезгуя ничем - убивать командующих, грабить новые деньги, взрывать мосты, учреждения, арсеналы, добывать оружие, препятствовать любым действиям врага! 15

И когда в ответ ему один из приятелей Бадая заявляет, что им и самим все понятно, а также, что все уже „поставлено на широкую ногу”, есть катакомбы, плана которых не может быть у противника (,Чуть что шасть под землю, и привет маме родной!”), Дунаев заключает:

- Ну, братва, вижу, что вас войной не испугаешь. Да только действия ваши теперь не на воровские цели должны быть потрачены, а на самую главную цель - на нашу общую Победу. А иначе - гибель, смерть всего, а для избранных рабство! 16

Образ Одессы в романе С. Ануфриева и П. Пепперштейна строится на основе оппозиции „тогда - теперь”, „Одесса всегда - военная Одесса”. Описывая появление Дунаева в городе, повествователь как бы присоединяется к своему герою и передает общее, возникающее у любого побывавшего в ней человека видение Одессы:

15 Tamże, s. 169-170.

16 Tamże, s. 170. 
Valentina Musiy, Topos "Odessa" in novel by Sergey Anufriev and Pavel Pepperstain...

Этот уходящий в неизбывное прошлое город был как сон, застилаемый поутру прозрачной дымкой и криками чаек. Его лепные балконы с бельем, мокроватая листва акаций, и загадочные дворики, открывающиеся на миг, в короткое мгновение поворота головы, когда проходишь по улице, и таинственные закоулки остаются за твоим плечом, порождая сожаление и роняя каштаны, как слезы...

Эти тенистые улицы, уютные и распластанные, как женщина на постели. Куда они ведут? Улицы переходят в улочки, с мусором в подворотнях и кошками на заборах из камня-дикаря. Улочки, тихие и сонные, перетекают в переулки, где стерлись номера дворов и уменьшились домики, где уже ноздри ощущают запах соленого моря и слышен шелест каштанов и черешен, продуваемых вечным ветром... ${ }^{17}$

Дворики, балконы, улицы Одессы начала войны предстают в новом облике:

Однако теперь Одесса была местом войны, настороженным городом воздушной тревоги и баррикад из мешков поперек улиц, с почерневшей лепниной на некогда пышных зданиях и снятым бельем, с настороженной тишиной дворов и заклеенными черной бумагой окнами, с раскатами канонады за околицами и унылыми очередями за хлебом, осыпаемыми пожухшей за жаркое лето листвой. Сумерки окутывали скверы, где еще недавно кипела жизнь, где торговали зажигалками, долларами и кокаином... 18

Одна из сигнатур Одесского текста - слова и выражения, которые традиционно связывают с „одесским языком”. Приведем ряд примеров.

Биндюжник: „По приличной улице в сапогах даже биндюжники не ходят, месье коммунар!"19. Сначала этим словом обозначали перевозщиков грузов на пароконной телеге (,биндюге”); позже оно стало применяться к любому грубому, невоспитанному человеку.

17 Tamże, s. 159-160.

18 Tamże, s. 160.

19 Tamże, s. 163. 
В темпе вальса: „Ну давай в темпе вальса, бо покусают боджолы!”20. Выражение употребляется в значении: „очень быстро”.

Малахольный (малохольный): „шо ты с ним связался? - томно сказала Раечка со своего сиденья. - Он же малахольный!"21. И далее следует фрагмент популярной одесской песни „С одесского кичмана бежали два уркана”: „Товарищ малахольный, / Скажи ты своей маме, что сын ее погибнул на посте - / С винтовкою в рукою, / И с саблею в другою, / И с песнею веселой на усте!”22. Слово „малахольный”, как пишет в „Таки да большом полутолковом словаре одесского языка" Валерий Смирнов, происходит от „малахавумеса”. Им „первоначально именовали только чересчур капризничающих детей либо взрослых людей, ведущих себя с детской дурацкой непосредственностью". Позже, как замечает этот автор, выражение стало употребляться в ситуациях, когда „точно невозможно определить степень больного с одесским диагнозом" 23 . Что же касается самой песни, то ее появление связано с постановкой пьесы из жизни одесских воров, которая шла в 1928 году в Ленинградском Театре сатиры. Пел ее Леонид Утесов, исполнявший в спектакле одну из ролей. До сегодняшнего дня дошло несколько вариантов песни „С одесского кичмана”.

Хипеш (хипиш): „Шо за хипеш? Козырный пришел? Шо, уже наши в городе?"24. Этим словом назывются все действия, которые сопровождаются „шумовыми эффектами” (шумом, криком, воем)”, в том числе, замечает В. Смиронов, и „хипес” - „ограбление с помощью красивой женщины легчайшего поведения" 25 .

Здесь, однако, следует сделать одну оговорку. Образ Одессы в романе создается условным, в нем больше от того, что можно обозначить как Одесский миф, Одесский текст, чем конкретно-исторического. Это

20 Tamże, s. 162.

21 Tamże, s. 163.

22 Tamże, s. 163-164.

23 В. Смирнов, Таки да большой полутолковый словарь одесского языка: в 4 т., Т. 2 , Одесса 2005, s. 299.

24 С. Ануфриев, П. Пепперштейн, dz. cyt., s. 162.

25 В. Смирнов, Таки да большой полутолковый словарь одесского языка: в 4 т., Т. 4, Одесса 2005, s. 341. 
относится и к тому, что именуется одесским языком. Так, слово „фраер”, которое мы встречаем в „Мифогенной любви каст”, безусловно, уже широко употреблялось в Одессе к 1940-м годам. Приведем цитату из „Мифогенной любви каст”: „...у подворотни прогуливался какойто типичный фраер - в клетчатом кепарике, с жеваной папироской в зубах, в дорогом белоснежном костюме с красной розой в петлице и в лакированных черно-белых штиблетах”26. Автор одессского „полутолкового словаря” В. Смирнов предлагает такую его этимологию:

Фраер, - человек, не относящийся к уголовной среде, потенциальная жертва. Одно из самых известных выражений за пределами одесского языка. Родилось в начале двадцатого века. Его автор - знаменитый Михаил Винницкий, он же Мишка Японец, а не Япончик, как ошибочно пишется во многих изданиях. Младший брат Винницкого вспоминал: во времена, когда Японец уже был признанным лидером, многие хотели пристать до его берега. Учитывая, что Японец был самым доступным для народа из всех известных тогда королей, к нему запросто попала на прием мадам по распространенной еще до недавних пор в Одессе фамилии Фраерман. Она так долго и нудно требовала от Винницкого устроить судьбу ее мало к чему пригодного сына, что в конце концов Японцу было легче согласиться, чем вытерпеть продолжение аудиенции. После минутной беседы с молодым человеком Винницкий выдал изречение: „Какой из тебя Фраерман? Вот Бушмак - тот таки Фраерман, а ты пока на больше, чем просто Фраер, не тянешь". Именно старый налетчик Фраерман по кличке Бушмак стал наставлять юношу по кличке Фраер на путь истинный. Таким образом дальнейшая эволюция Ф. породила ряд известных за пределамим одесского языка выражений. Первоначально Ф. означало „неопытный преступник"27.

А вот слова „деловар”, смеем предположить, еще не было в одесском языке. В „Мифогенной любви каст” оно встречается в таком фрагменте: „...еще недавно в свете огней проходили богатые еврейские се-

26 С. Ануфриев, П. Пепперштейн, dz. cyt., s. 163.

27 В. Смирнов, Таки да большой полутолковый словарь одесского языка: в 4 т., Т. 4. , dz. cyt., s. 303-304.. cyt., s. 44. 
мьи и “деловары”...”28. Это слово - одесский синоним слова „деляги”, „предприимчивые люди”. Поясняя, почему слово „деловар” произносилось в Одессе с „придыханием”, Валерий Смирнов пишет: „Ведь деловар - это не заурядный фарцовщик, это самый настоящий цеховик (артельщик), воротила теневой экономики”29. Однако само по себе явление „теневая экономика", относится, скорее, к послевоенным, 1970-1990-м годам.

Подобная условность включения в роман сигнатур одесского текста относится к, пожалуй, еще более знаковой его составляющей - песням. В „Мифогенной любви каст” „звучит” много песен об Одессе. Они разного плана: блатные, героические и лирические; авторские, фольклорные, а также авторские, но позже перешедшие в фольклор, когда к сочиненному автором тексту исполнителями добавлялись новые куплеты, и текст песни постепенно утрачивал признаки индивидуального авторства. В связи с этим сложно подчас атрибутировать, кому принадлежит песня и, даже точно сказать, одесская ли она (как, к примеру, цитируемая в романе „На Дерибасовской открылася пивная”, по поводу которой до сих пор ведутся споры: она является ростовской или же одесской). Приведем несколько примеров.

Еще до войны была написана, подписанная псевдонимом „М. Любин” песня „Ах, Одесса, жемчужина у моря...”. Автор слов и мелодии - Модест Ефимович Табачников. Однако впоследствии, с каждым новым исполнением к сочиненному им тексту добавлялись новые куплеты. В результате „Ах, Одесса, жемчужина у моря” перешла в разряд „народных”.

К довоенным относится и „Ах, лимончики...” - песня об украшениях квартир, а также обесценивавшихся миллионах рублей. Песня была сочинена Василием Лебедевым-Кумачом и Львом Зингерталем (возможно, при участии автора „Бубличков” Якова Ядова) в 1920-е годы. К ней также „приращивались” исполнителями куплеты, превращая ее в „народную”. С 1929 года песня вошла в репертуар Леонида Утесова.

А вот „Золотые огоньки” из репертуара того же Леонида Утесова, строки которой „В тумане скрылась милая Одесса, / Золотые огоньки! / Не горюйте, ненаглядные невесты, / В сине море вышли моряки!"

29 В. Смирнов, Крошка Цахес Бабель, Одесса 2009, s. 281. 
открывают „одесскую” главу романа „Мифогенная любовь каст”, была написана А. Фатьяновым (по некоторым источникам - при участии С. Фогельсона) позже, уже после победы, в 1946-1947 гг. Музыку к ней сочинил В. П. Соловьев-Седой. Еще позже, в 1968 году, были написаны „Но я не плачу...” - куплеты Бубы Касторского из „Приключений неуловимых мстителей”. Автор слов - конферансье Мосэстрады Эмиль Радов, музыки - Ян Френкель. Это же относится и к песне про Мясоедовскую улицу. В „Мифогенной любви каст” читаем:

Через пару кварталов Дунаев остановился и вытащил из кармана пыльника бумажку, где витиеватым белогвардейским почерком Холеного была обозначена явочная квартира: „Мясоедовская, угол Степовой, дом 18, спросить Сеню Головные Боли". Он посмотрел на дом и увидел, что это как раз тот самый дом на Мясоедовской:

Улица, улица

Улица родная, Мясоедовская улица моя! 30

По поводу авторства песни мнения разноречивы. Кто-то называет Мориса Бунимовича, кто-то - Майкла Бахмана... Примечательно, что оба признаются, что текст у них как-то „случился”, сочинялся легко, вбирая в себя множество одесских образов. Возможно, поэтому „Есть у нас в районе Молдованки...” и стала частью городского фольклора. Однако в любом случае история ее начинается в 1960-е годы.

Многие другие сигнатуры Одесского текста (Дерибасовская, Аркадия, Соборка и так далее), хотя и включены авторами первого тома „Мифогенной любви каст" в военный контекст, предстают в воображении читателя независимо от конкретных исторических событий. В романе это мотивировано тем, что видит их Дунаев, который и раньше бывал в Одессе и теперь вспоминает, какой она была в мирное время.

Вот здесь, среди роз, перед Археологическим музеем стояла статуя Лаокоона с сыновьями, обвитыми изящными змеями, вот здесь, мимо Англий- 
ского клуба, а ныне Морского музея, он гулял с Полиной после „Травиаты” в Оперном театре. А вот и сам Оперный театр, как утверждали одесситы, идентичный венскому, но лучше его. Вот и дом, где жил Пушкин, вот Ришельевская улица, где он прогуливался с очередной дамой сердца...

Заметим, что „Лаокоона” Дунаев не мог видеть около Археологического музея ни до войны, ни с ее началом, поскольку эта скульптурная группа, являющаяся копией той, что хранится в Ватикане, была выполнена по заказу городского головы Одессы (с 1878 по 1895 гг.) Григория Григорьевича Маразли и установлена (в 1870 году) на его даче. После национализации в результате революции 1917 года местоположение скульптуры менялось шесть раз. Долгое время она находилась в скверике возле Дома культуры армии и флота на пересечении Преображенской и Спиридоновской улиц (там сейчас находятся скульптурные изображения героев книги Валентина Петровича Катаева „Белеет парус одинокий” Гаврика и Пети). И только в 1971 году эта скульптура была установлена возле Археологического музея.

Подобные отступления от фактов в романе объясняются тем, что Одесса, как и любовь каст, имеют в нем „мифогенное” происхождение. Это реальный город со своими топографией, историей, культурой. Город, в котором родился и вырос один из авторов романа - Сергей Ануфриев. И в то же время это город, который превратился в миф, или точнее - сверхтекст, то есть сложная система „интегрированных текстов, имеющих общую внетекстовую ориентацию, образующих незамкнутое единство, отмеченное смысловой и языковой цельностью"з1. У каждого человека, даже не бывавшего в Одессе, само по себе ее имя рождает картину порта, моря, моряков, ленивых фигур отдыхающих, наслаждающихся тесным сплетением в Одессе прошлого и настоящего, быта и искусства, человека и щедрой к нему южной природы. Для большинства представляющих себе Одессу, как и живущих в ней, это город, где все весельем дышит, беспечный, ироничный и в то же гордящийся собой и умеющий за себя постоять. В таком облике и предстает город на страницах одной из глав первого тома романа С. Ануфриева и П. Пепперштейна.

31 Е. Меднис, Поэтика и семиотика русской литературы, Москва 2011. 
Valentina Musiy, Topos "Odessa" in novel by Sergey Anufriev and Pavel Pepperstain...

\section{Literatura}

Ануфриев С., Пепперштейн П., Мифогенная любовь каст, Москва 1999.

Бабич А., Как организовывалось одесское подполье, „Дерибасовская - Ришельевская. Альманах" 2013, № 3(54), с. 53-66.

Булгакова А. А., Топика в литературном процессе, Гродно 2008.

Крикливец Е. В., Художественный мир В. Астафьева и В. Козько: пространственно-временная организация, Витебск 2014.

Литературная энциклопедия терминов и понятий, под ред. А. Н. Николюкина, Москва 2003.

Лотман Ю. М., В школе поэтического слова: Пушкин. Лермонтов. Гоголь: Книга для учителя, Москва 1988.

Маркова Д. А., История как сказка: освоение военного мифа в романе «Мифогенная любовь каст», „Знание. Понимание. Умение” 2005, № 2, с. 164-176.

Меднис Н. Е., Поэтика и семиотика русской литературы, Москва 2011.

Прокофьева В. Ю., Категория пространство в художественном преломлении: локусы и топосы, „Вестник Оренбургского гос. ун-та” 2005, № 11, с. 87-94.

Смирнов В., Крошка Цахес Бабель, Одесса 2009.

Смиирнов В., Таки да большой полутолковый словарь одесского языка в четырех томах, Одесса 2005.

\section{Bibliografia}

Anufriyev S., Peppershteyn P., Mifogennaya lyubov' kast, Moskva 1999.

Babich A., Kak organizovyvalos' odesskoye podpol'ye, „Deribasovskaya Rishel'yevskaya. Al'manakh" 2013, № 3(54). s. 53-66.

Bulgakova A. A., Topika v literaturnom protsesse, Grodno 2008.

Kriklivets Ye. V., Khudozhestvennyy mir V. Astaf'yeva i V. Koz'ko: prostranstvennovremennaya organizatsiya, Vitebsk 2014.

Literaturnaya entsiklopediya terminov i ponyatiy, pod red. A. N. Nikolyukina, Moskva 2003.

Lotman Yu. M., V shkole poeticheskogo slova: Pushkin. Lermontov. Gogol': Kniga dlya uchitelya, Moskva 1988.

Markova D. A., Istoriya kak skazka: osvoyeniye voyennogo mifa v romane «Mifogennaya lyubov' kast», „Znaniye. Ponimaniye. Umeniye” 2005, № 2, s. 164-176. 
Mednis N. Ye., Poetika i semiotika russkoy literatury, Moskva 2011.

Prokof'yeva V. Yu., Kategoriya prostranstvo $v$ khudozhestvennom prelomlenii: lokusy i toposy, „Vestnik Orenburgskogo gos. un-ta” 2005, № 11, s. 87-94.

Smirnov V., Kroshka Tsakhes Babel', Odessa 2009.

Smiirnov V., Taki da bol'shoy polutolkovyy slovar' odesskogo yazyka v chetyrekh tomakh, Odessa 2005. 